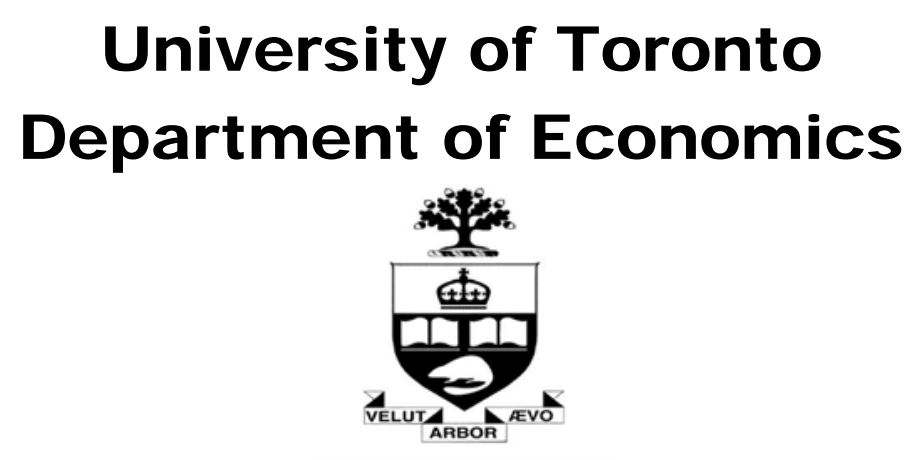

Working Paper 605

The Varying Shadow of China's Banking System

By Xiaodong Zhu

May 17, 2018 


\title{
The Varying Shadow of China's Banking System*
}

\author{
Xiaodong Zhu \\ University of Toronto \\ First Draft: November 14, 2017 \\ Revised: February 1, 2018
}

\begin{abstract}
The rapid rise of shadow banking activities in China since 2009 has attracted a great deal of attention in both academia and policy circles. Most existing studies and commentary on China's shadow banking have treated it as a recent phenomenon that appeared after the Global Financial Crisis and China's response to it. In this paper, I argue that shadow banking is not a new phenomenon; it has always been a part of China's financial system since the 1980s, and arose from the need to get around various lending restrictions imposed by the central government on banks. I also emphasize that there are two types of shadow banking activities, those initiated by banks and those initiated by local governments or state-owned enterprises. I provide evidence suggesting that the shadow banking activities initiated by banks tend to be efficiency enhancing, but those initiated by local governments and state-owned enterprises are more likely to be associated with misallocation of capital. The policy implication is that the central government should implement policies and regulations that break the link between financial institutions and local governments or state-owned enterprises.
\end{abstract}

\footnotetext{
* Corresponding email address: xzhu@,chass.utoronto.ca. I would like to thank Yanhao Wang and Wenna Zhong for their excellent research assistance. I would also like to thank Joshua Aizenman, Hanming Fang, Zhiguo He, Zheng Liu, Mark Spiegel, Guofeng Sun, and participants at the San Francisco Fed APEC Conference as well as seminars in Shanghai Advanced Institute of Finance (SAIF) and PBC School of Finance (PBCSF) for their useful comments. Part of the research of this paper was done when I visited SAIF in the fall of 2017, and I would like to thank SAIF for its hospitality and financial support.
} 


\section{Introduction}

Since 2009, shadow banking activities have grown rapidly in China. Figure 1 shows the breakdown of loans to non-financial sectors in China by four major sources: bank loans, entrusted loans, trust loans and bankers' acceptances. Entrusted loans are loans made on behalf of large companies by banks, trust loans are loans made by trust companies, and bankers' acceptances are notes issued by banks on behalf of non-financial firms. The later three types of loans are the main forms of shadow bank lending in China. Their share of total credits in China was less than 12 percent in 2009 and almost 18 percent in 2016. This rapid rise of shadow banking activities has attracted a great deal of attention in both policy circles $^{1}$ and academia. ${ }^{2}$ Is shadow banking a new phenomenon in China? What are the driving forces behind China's shadow banking activities? How does shadow banking affect China's real economy? These are the questions that I will address in this paper.

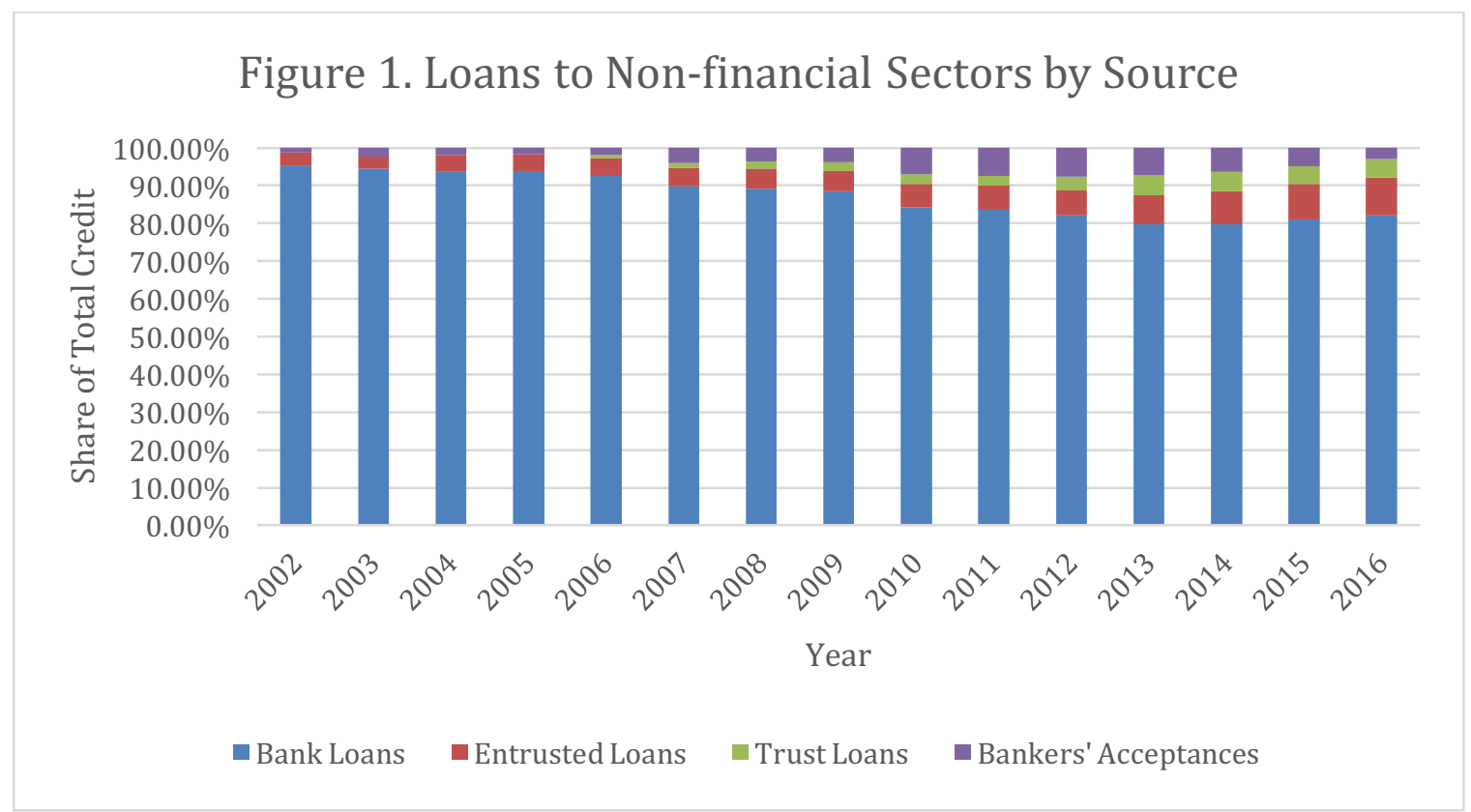

Source: People's Bank of China.

\footnotetext{
${ }^{1}$ See, for example, Elliott, Krueber and Qiao (2015), Sheng, Edelmann, Sheng and Hu (2015), and the IMF's Global Financial Stability Reports and FSB's Global Shadow Banking Monitoring Reports since 2011.

2 See Hachem and Song (2015), Acharya, Qian and Yang (2016), Allen, Qian, Tu and Yu (2016), Bai, Hsieh and Song (2016), Wang, Wang, Wang and Zhou (2016), Chen, Ren and Zha (2017), Chen, He and Liu (2017) and Allen, Gu, Qian and Qian (2017).
} 
I will argue that shadow banking is not a new phenomenon; it has always been a part of China's financial system since the 1980s, and arose from the need to get around various lending restrictions imposed by the central government on banks. I will also emphasize that there are two types of shadow banking activities, those initiated by banks and those initiated by local governments or state-owned enterprises (SOEs). Finally, I will provide evidence suggesting that the shadow banking activities initiated by banks tend to be efficiency enhancing, but those initiated by local governments and SOEs are more likely to be associated with misallocation of capital. The policy implication is that the central government should implement regulations that limit the link between financial institutions and local governments or state-owned enterprises.

Related Literature Most recent studies on China's shadow banking have treated it as a new phenomenon that appeared after the Global Financial Crisis in 2008 and China's response to it in 2008-2009. Hachem and Song (2015) and Acharya, Qian and Yang (2016) both focus on the liability side of shadow banking - the rise of the wealth management products (WMPs) issued by banks - and attribute the origins of it to the adoption of stricter liquidity rules by the Chinese regulators in the late 2000s and the implementation of the fiscal stimulus plan by the Chinese government in 2008-2009, respectively. Allen, Qian, $\mathrm{Tu}$ and $\mathrm{Yu}$ (2016) and Chen, Ren and Zha (2017) use detailed transaction-level data on entrusted loans to study the pricing of entrusted loans and the interaction between monetary policy and shadow banking, respectively; and Allen, Gu, Qian and Qian (2017) study the pricing of implicit guarantees of trust products by local governments. Bai, Hsieh and Song (2016) examine how local governments use the so-called local financing vehicles to raise funds through the shadow banking sector and direct those funds to their favored businesses. They argue that this type of shadow banking activities has reduced the overall efficiency of capital allocation. Wang, Wang, Wang and Zhou (2016), on the other hand, argue theoretically that shadow banking in China is mainly used by banks to evade excessive credit control by the government, which helps to improve the resource allocation in the economy. Chen, He and Liu (2017) use provincial data to argue that the rapid increase in municipal corporate bonds and shadow banking activities such as entrusted loans and WMPs stem from local governments' need to rollover the huge amounts of loans they took 
out from banks during the fiscal stimulus period of 2008-2009. Sun and Jia (2015) also emphasize the difference between the shadow banking activities of banks and the lending activities of shadow banks, and provides estimates of the scale of the former type of activities. Ho, Li, Tian and Zhu (2017) use detailed loan-level micro data to study the differential impacts of the central government's fiscal stimulus policy on a state-owned bank's on-balance-sheet and off-balance-sheet lending activities. There is also a small earlier literature on shadow banking in China. Brandt and Zhu (1995) and Kumar et. al. (1996) examine in detail the behavior of the nonbank financial institutions in China; Brandt and Zhu (2000) emphasize the important role played by the nonbank financial institutions in China's credit allocation, growth and inflation cycles in the 1980s and early 1990s; and Brandt and Zhu (2007) discuss the recentralization of China's banking system since the mid-1990s and its implication for credit allocation and growth in the economy.

\section{China's Banking System}

As a background, I first discuss the evolution of China's banking system during the reform period. In 1978, on the eve of economic reform, China had a fully centralized monobank system with the People's Bank of China (PBC) serving as both the central bank and the only commercial bank. After the launch of economic reform in December 1978, the Chinese government started to decentralize the banking system. Between 1979 and 1984, the commercial banking responsibilities were gradually devolved from the $\mathrm{PBC}$ to four newly established or reestablished state-owned banks: Agricultural Bank of China (ABC), Bank of China (BOC), China Construction Bank (CCB), and Industrial and Commercial Bank of China (ICBC). A policy bank, China Investment Bank, was established in 1981 to handle loans to China from international organizations such as the World Bank. In addition, several joint-stock banks were also established to introduce more competition in the banking sector. Table 1 lists the number of banks by type in China since 1986. By 1993, China's banking system included one policy bank, four state-owned commercial banks and ten joint-stock banks.

In 1994, China launched a new round of banking reform. Three policy banks, China Development Bank, China Agricultural Development Bank and China Export and Import 
Bank, were established to take over the remaining policy lending responsibilities from the four state-owned commercial banks. The formal banking sector was further diversified by establishing City Commercial Banks in all of the major cities in China and later Rural Commercial Banks as well in some of the cities. After China's accession to WTO, entry of foreign banks was also allowed. So, in terms of both the types and number of banks, it seems that China's banking system has steadily become more diverse and more competitive over time.

\begin{tabular}{|c|c|c|c|c|c|c|c|c|c|c|}
\hline \multirow[b]{2}{*}{ Year } & \multirow[b]{2}{*}{$\begin{array}{l}\text { Policy } \\
\text { Banks }\end{array}$} & \multicolumn{5}{|c|}{ Domestic Commercial Banks } & \multicolumn{3}{|c|}{ Nonbank Lending Institutions } & \multirow[b]{2}{*}{$\begin{array}{c}\text { Foreign } \\
\text { Banks }\end{array}$} \\
\hline & & $\begin{array}{c}\text { State- } \\
\text { owned } \\
\text { Banks }\end{array}$ & $\begin{array}{c}\text { Joint Stock } \\
\text { Banks }\end{array}$ & $\begin{array}{c}\text { City } \\
\text { Commercia } \\
\text { I Banks }\end{array}$ & $\begin{array}{c}\text { Rural } \\
\text { Commercia } \\
\text { I Banks } \\
\end{array}$ & $\begin{array}{c}\text { Rural } \\
\text { Cooperativ } \\
\text { e Banks } \\
\end{array}$ & \begin{tabular}{|c} 
Urban \\
Credit \\
Cooperativ \\
es
\end{tabular} & $\begin{array}{c}\text { Rural Small } \\
\text { Financial } \\
\text { Institutions }\end{array}$ & $\begin{array}{c}\text { Trust and } \\
\text { Investment } \\
\text { Companies }\end{array}$ & \\
\hline 1986 & 1 & 4 & 1 & & & & 1151 & 60872 & & \\
\hline 1989 & 1 & 4 & 7 & & & & 3409 & 58200 & & \\
\hline 1990 & 1 & 4 & 7 & & & & 3421 & 57927 & & \\
\hline 1991 & 1 & 4 & 7 & & & & 3518 & 52763 & 375 & \\
\hline 1992 & 1 & 4 & 10 & & & & 4001 & 50865 & 386 & \\
\hline 1993 & 1 & 4 & 10 & & & & 4957 & 50745 & 388 & \\
\hline 1998 & 3 & 4 & 12 & & & & 3190 & 41755 & 239 & \\
\hline 1999 & 3 & 4 & 12 & 90 & & & 836 & 40141 & 238 & \\
\hline 2000 & 3 & 4 & 12 & 99 & & & & 38067 & & \\
\hline 2001 & 3 & 4 & 12 & 109 & & & & 38057 & & \\
\hline 2002 & 3 & 4 & 12 & & & & & 35544 & & \\
\hline 2003 & 3 & 4 & 13 & & & & & 33979 & & \\
\hline 2004 & 3 & 4 & 13 & 112 & 7 & 12 & 681 & 32888 & 59 & 14 \\
\hline 2005 & 3 & 4 & 13 & 113 & 12 & 58 & 599 & 27101 & & 14 \\
\hline 2006 & 3 & 5 & 12 & 113 & 13 & 80 & 78 & 19441 & 54 & 14 \\
\hline 2007 & 3 & 5 & 12 & 124 & & & 42 & 8509 & 54 & 29 \\
\hline 2015 & 3 & 5 & 12 & 133 & 859 & 71 & 0 & 3662 & 68 & 40 \\
\hline 2016 & 3 & 5 & 12 & 134 & 1114 & 40 & 0 & 3722 & 68 & 43 \\
\hline
\end{tabular}

Source: Almanac of China's Finance and Banking, various years.

How does the evolution of the banking system affect capital allocation in China? In a joint paper with Loren Brandt and Trevor Tombe (Brandt, Tombe and Zhu, 2013), we examined factor allocation in China's non-agricultural economy between 1985 and 2007, 
and found that returns to capital were much lower in the state sector than in the non-state sector - even after controlling for regional differences. We view this as a clear sign of misallocation of capital. Figure 2 plots our estimate of aggregate TFP loss due to misallocation of capital between the state and non-state sectors for each year during the period from 1985 to 2007 . The TFP loss is calculated by comparing the actual aggregate TFP to the counterfactual aggregate TFP when capital is reallocated between the state and non-state sectors so that returns are equalized between the two sectors within each province in China. In the 1980s and early 1990s, capital allocation improved as a more decentralized banking system allocated more credits to the non-state sector. Surprisingly, however, after the start of the banking reform in 1994 and despite the establishment of a large number of city and rural commercial banks, capital allocation stopped to improve. In fact, since then misallocation of capital was getting worse over time. By 2007, the TFP loss due to capital misallocation was as high as in 1985 . Why the banking reform failed to improve the overall efficiency of capital allocation in China? I will argue that the answer lies in what happened in the shadow of China's banking system, more specifically, what happened to the nonbank lending institutions in China.

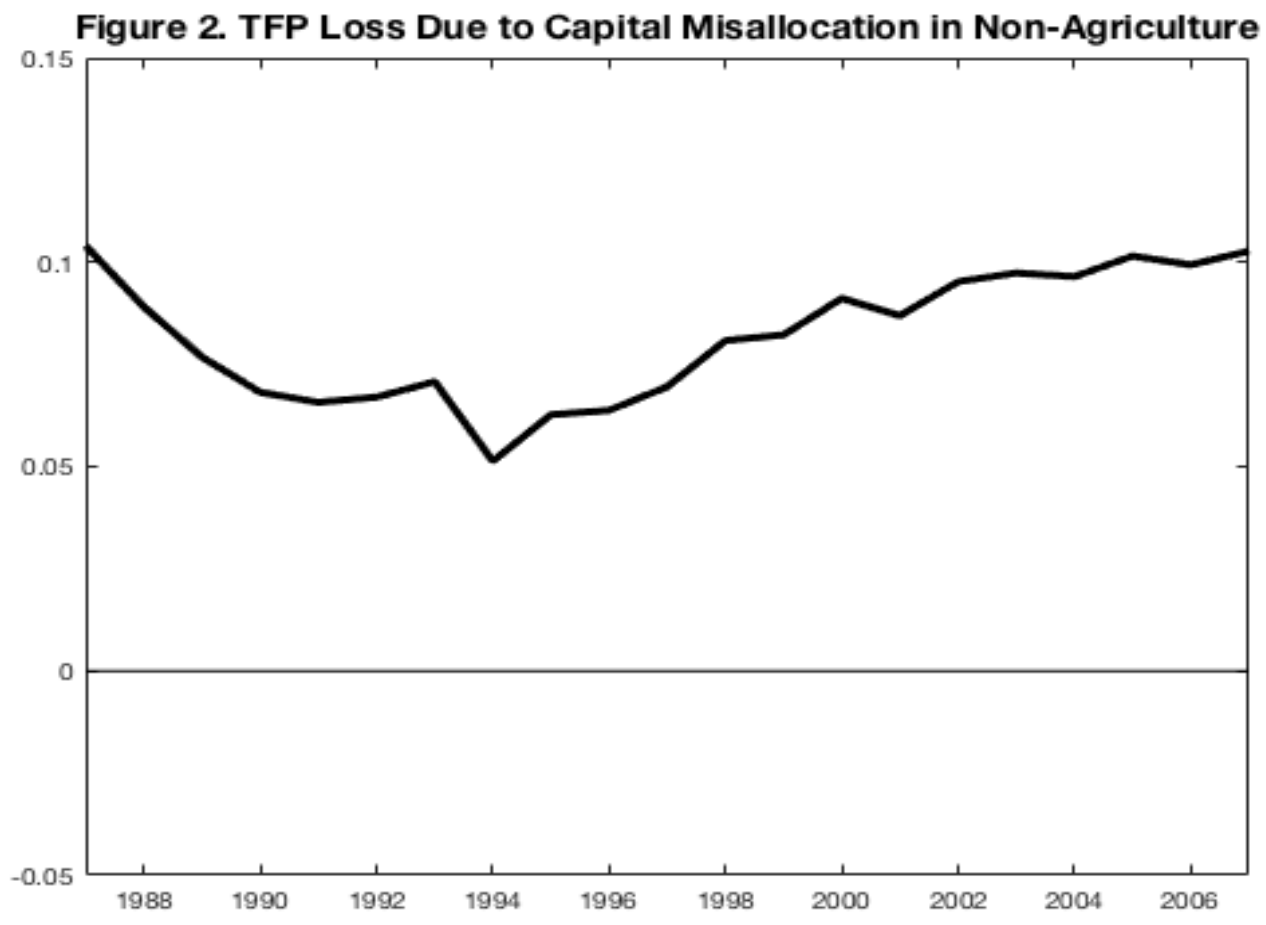

Source: Brandt, Tombe and Zhu (2013) 


\section{The Nonbank Lending Institutions and Overall Credit Allocation}

In addition to the policy banks and commercial banks, there are other nonbank lending institutions in China. Because the Chinese central government has always imposed significant constraints on banks' lending decisions - through detailed credit plans and credit quotas in the years prior to 1998 and through various regulations and window guidance since 1998, nonbank lending institutions have played an important role in the overall credit allocation in China. The most prominent nonbank lending institutions are the trust and investment companies (TICs), urban credit cooperatives (UCCs) and rural credit cooperatives (RCCs). Other nonbank lending institutions include finance companies and leasing companies, but their shares of total credits have been very small. Therefore, my discussion here will focus on the TICs, UCCs and RCCs.

\section{Nonbank Lending Institutions in the 1980s and Early 1990s}

Trust and Investment Companies Prior to 1994, TICs can be broadly grouped into two types: those affiliated with banks and those that were set up by local governments or large SOEs. Because the TICs were less regulated than banks and therefore had more flexibility in credit allocation, banks had strong incentives to set up affiliated TICs as a way to get around the central government's restriction on loans; in the 1980s and early 1990s, almost all local branches of the state-owned banks in major cities had their own affiliated TICs. Local governments and large SOEs also had strong incentives to set up TICs so that they could use them to direct funds to their favorite projects. Not surprisingly, the number of TICs increased rapidly in the 1980s. In 1987, the first year when the PBC started to report the number of TICs, there were already 561 of them. Within one year, the number increased by more than 30 percent, to 745 in 1988 . The growth, however, was checked by the central government as it became concerned about the role of the TICs in diverting funds from the state-owned banks. About half of the TICs were closed down by the central government during a two-year crack-down in 1989-90. The restriction on the growth of TICs was relaxed after Deng Xiaoping's push for further market reforms during his famous tour of southern China in 1992. The number of TICs increased again, but modestly from 375 in 1991 to 391 in 1994. 
Urban Credit Cooperatives UCCs were community-based credit cooperatives that mainly served the financing needs of local small and medium-sized enterprises in the nonstate sector. Because these enterprises had difficulty getting loans from the state-owned banks, their demand for credits from UCCs were high. The first UCC was established in 1979. By 1986 there were more than one thousand UCCs in China. This growth happened despite the uncertain legal status of UCCs, and accelerated after 1986 when the PBC formally sanctioned UCCs as legal deposit-taking and lending institutions. Similar to the TICs, some of the UCCs were also set up by the local branches of the state-owned banks as a way to get around the central government's restrictions on their lending activities and their growth were also checked in 1989-90 as the central government tightened regulations of all nonbank financial institutions. Again, like the TICs, the growth of UCCs resumed in 1992 after Deng Xiaoping's southern tour.

Rural Credit Cooperatives RCCs have a much longer history than TICs and UCCs in China. They were first established in the early 1950s as rural credit unions at township and village levels to meet farmers' needs for savings and loans. In the 1980s they were brought under the direct supervision of local branches of the Agricultural Bank of China (ABC) and therefore had strong connections with the formal banking system. By 1986 there were more than six thousand RCCs in China, and they became a major source of financing for the township and village enterprises or TVEs - the rural non-state enterprises that were the engine of China's growth in the 1980s and early 1990s.

In summary, the UCCs, RCCs and TICs are important nonbank lending institutions that, in the 1980s and early 1990s, had strong connections to the state-owned commercial banks and, at the same time, faced less restrictions on their lending decisions. They were the shadow banks in China during that period. Their flexibility in credit allocation and their links to banks greatly facilitated the diversion of funds from the formal banking system for lending to non-state enterprises outside the central government's credit plans. As documented by Brandt and Zhu $(1995,2000)$, the central government's regulation of these nonbank lending institutions fluctuated between strict and lax during this period, so did the role of these institutions in the overall credit allocation of the economy. Table 2 reports the 
amounts of outstanding loans made by these nonbank lending institutions and their shares of total credits in the economy. The data source is the Almanac of China's Finance and Banking published annually by the PBC. The share of total credits accounted for by the TICs, RCCs and UCCs together had an upward trend between 1986 and 1996, but the speed of increase fluctuated significantly. The fluctuations were particularly pronounced for the TICs. In 1995, these three types of nonbanking lending institutions together accounted for 19 percent of loans by all financial institutions. Since 1996, however, these institutions' shares of total credits generally declined as a result of the banking reform launched in 1994 and the associated recentralization of China's banking system. In 2009, their share of total credit was only 9.42 percent.

\section{Banking Reform in 1994 and Recentralization of the Banking System}

With the launch of the banking reform in 1994, the central government took several measures that affected all three major types of the nonbank lending institutions. First, the number of TICs declined yet again as another round of crack-down began. This time, in an effort to eliminate diversion of funds by the state-owned banks, all the bank-affiliated TICs were shut down within a few years. What remained after this round of crack-down were the TICs controlled by local governments and large SOEs.

Second, the central government stopped approving applications for establishing new UCCs, and, in 1995, started a process of consolidation. UCCs were gradually consolidated into much larger city commercial banks with the local city governments as the controlling shareholders. The number of UCCs declined rapidly during this consolidation process and the last UCC was officially closed in 2012.

Finally, the central government severed the links between the RCCs and local branches of $\mathrm{ABC}$, and put RCCs under direct supervision of the $\mathrm{PBC}$ and later the China Banking Regulatory Commission (CBRC). A consolidation process also began in the late 1990s, during which RCCs in the surrounding areas of urban city centers were consolidated into large rural commercial banks. Despite their names, these rural commercial banks are generally located in urban city centers and they behave very much like the city commercial 
banks. The ownership structure of these banks also changed from collective to shareholding companies with the SOEs as the controlling shareholders. For example, when the Beijing Rural Commercial Bank was established in 2005, its three largest shareholders were all SOEs under the supervision of the Beijing city government: Beijing State-Owned Asset Management Co. Ltd., Beijing Capital Group Company Ltd., and Beijing Huarong Investment Company. The headquarter of the bank is located in the downtown financial district in Beijing, and by asset it was ranked 401 in 2006 among the list of Top 1000 World Banks published by The Banker magazine in England.

\section{The Role of Nonbank Lending Institutions in Credit Allocation}

Because the UCCs and RCCs lend mainly to small and medium-sized enterprises in the non-state sector, their rise in the 1980s and early 1990s played an important role in the improvement of capital allocation we saw in Figure 2. In Figure 3, I plot the share of shortterm non-agricultural loans made by all financial institutions that went to the state-owned enterprises (SOEs). Comparing Figure 3 to Figure 2, one can see that capital misallocation is strongly associated with the SOEs' share of short-term credits to non-agricultural enterprises, which fluctuated around a declining trend from 1985 to 1996, but then reversed the course and trended upward. The reversal is a result of the banking reform in 1994. As we discussed earlier, the UCCs and RCCs have been gradually consolidated into much larger city and rural commercial banks, which are under the control of local governments and generally favor large enterprises over small and medium-sized enterprises in their credit allocation. Wang (2017), for example, uses city-level panel data to study the impact of city commercial banks on local economic growth. He finds that between 1999 and 2007, firms in cities with newly established city commercial banks had significantly lower growth rates than firms in other cities, and the negative effect is particularly strong for small firms. This evidence suggests that the recentralization of the banking system is one of the reasons behind the increased misallocation of capital after $1994 .^{3}$

\footnotetext{
${ }^{3}$ Another important reason for increased capital misallocation is the fiscal reform that was carried out at the same time when the banking reform started. By implementing a centralized value-added tax system, the fiscal reform put significantly more resources at the disposal of the central government, which used the resources for regional and industrial policies that effectively favored investment in the state sector. See Brandt, Tombe and Zhu (2013) for a more detailed analysis of this.
} 


\begin{tabular}{|c|c|c|c|c|c|c|c|c|c|c|}
\hline \multirow[t]{2}{*}{ Year } & \multicolumn{2}{|c|}{ All } & \multicolumn{2}{|c|}{ RCC } & \multicolumn{2}{|c|}{ UCC } & \multicolumn{2}{|c|}{ TIC } & \multicolumn{2}{|c|}{ RCC+UCC+TIC } \\
\hline & Amount & $\begin{array}{c}\text { share of } \\
\text { total }\end{array}$ & amount & $\begin{array}{l}\text { share } \\
\text { of total }\end{array}$ & amount & $\begin{array}{l}\text { of } \\
\text { total }\end{array}$ & amount & $\begin{array}{l}\text { share } \\
\text { of total }\end{array}$ & amount & $\begin{array}{c}\text { share of } \\
\text { total }\end{array}$ \\
\hline 1986 & 8353.78 & 100.00 & 568.51 & 6.81 & 19.50 & 0.23 & 217.80 & 2.61 & 805.81 & 9.65 \\
\hline 1987 & 10269.11 & 100.00 & 772.35 & 7.52 & 63.40 & 0.62 & 439.60 & 4.28 & 1275.35 & 12.42 \\
\hline 1988 & 12219.50 & 100.00 & 908.60 & 7.44 & 133.90 & 1.10 & 660.60 & 5.41 & 1703.10 & 13.94 \\
\hline 1989 & 14360.20 & 100.00 & 1090.72 & 7.60 & 196.30 & 1.37 & 694.40 & 4.84 & 1981.42 & 13.80 \\
\hline 1990 & 17680.70 & 100.00 & 1413.00 & 7.99 & 248.80 & 1.41 & 890.60 & 5.04 & 2552.40 & 14.44 \\
\hline 1991 & 21337.80 & 100.00 & 1808.00 & 8.47 & 316.20 & 1.48 & 1211.00 & 5.68 & 3335.20 & 15.63 \\
\hline 1992 & 26322.90 & 100.00 & 2454.00 & 9.32 & 497.40 & 1.89 & 1697.10 & 6.45 & 4648.50 & 17.66 \\
\hline 1993 & 32943.10 & 100.00 & 3144.00 & 9.54 & 777.50 & 2.36 & 2052.00 & 6.23 & 5973.50 & 18.13 \\
\hline 1994 & 40810.10 & 100.00 & 4168.60 & 10.21 & 1323.60 & 3.24 & 2031.50 & 4.98 & 7523.70 & 18.44 \\
\hline 1995 & 50394.20 & 100.00 & 5234.20 & 10.39 & 1929.00 & 3.83 & 2409.80 & 4.78 & 9573.00 & 19.00 \\
\hline 1996 & 61152.80 & 100.00 & 6364.70 & 10.41 & 2445.20 & 4.00 & 2336.90 & 3.82 & 11146.80 & 18.23 \\
\hline 1997 & 74914.10 & 100.00 & 7273.21 & 9.71 & N/A & N/A & 2322.10 & 3.10 & N/A & N/A \\
\hline 1998 & 86524.10 & 100.00 & 8340.18 & 9.64 & $\mathrm{~N} / \mathrm{A}$ & N/A & 2521.30 & 2.91 & N/A & N/A \\
\hline 1999 & 93734.30 & 100.00 & 9225.59 & 9.84 & $\mathrm{~N} / \mathrm{A}$ & N/A & 2504.60 & 2.67 & N/A & N/A \\
\hline 2000 & 99371.07 & 100.00 & 10489.29 & 10.56 & $\mathrm{~N} / \mathrm{A}$ & N/A & 2409.71 & 2.42 & N/A & N/A \\
\hline 2001 & 112314.70 & 100.00 & 11971.16 & 10.66 & $\mathrm{~N} / \mathrm{A}$ & N/A & 2497.60 & 2.22 & N/A & N/A \\
\hline 2002 & 131293.93 & 100.00 & 13937.71 & 10.62 & 664.45 & 0.51 & 2170.31 & 1.65 & 16772.47 & 12.77 \\
\hline 2003 & 158996.23 & 100.00 & 16978.69 & 10.68 & 836.90 & 0.53 & 2281.32 & 1.43 & 20096.91 & 12.64 \\
\hline 2004 & 178197.78 & 100.00 & 19237.84 & 10.80 & 1014.54 & 0.57 & 2721.17 & 1.53 & 22973.55 & 12.89 \\
\hline 2005 & 194690.39 & 100.00 & 18680.86 & 9.60 & 1131.14 & 0.58 & 3126.17 & 1.61 & 22938.17 & 11.78 \\
\hline 2006 & 225347.20 & 100.00 & 20681.90 & 9.18 & 1006.55 & 0.45 & 2518.71 & 1.12 & 24207.16 & 10.74 \\
\hline 2007 & 261690.88 & 100.00 & 24121.61 & 9.22 & 846.74 & 0.32 & 2356.28 & 0.90 & 27324.63 & 10.44 \\
\hline 2008 & 303467.77 & 100.00 & 27452.32 & 9.05 & 435.34 & 0.14 & 3026.43 & 1.00 & 30914.09 & 10.19 \\
\hline 2009 & 399684.82 & 100.00 & 32156.31 & 8.05 & 213.50 & 0.05 & 5276.63 & 1.32 & 37646.44 & 9.42 \\
\hline 2010 & 479195.55 & 100.00 & 33972.91 & 7.09 & 66.23 & 0.01 & N/A & N/A & N/A & $\mathrm{N} / \mathrm{A}$ \\
\hline 2011 & 547946.69 & 100.00 & 36715.91 & 6.70 & 36.83 & 0.01 & N/A & $\mathrm{N} / \mathrm{A}$ & $\mathrm{N} / \mathrm{A}$ & $\mathrm{N} / \mathrm{A}$ \\
\hline
\end{tabular}

Source: Almanac of China's Finance and Banking, various years, and author's calculation. 


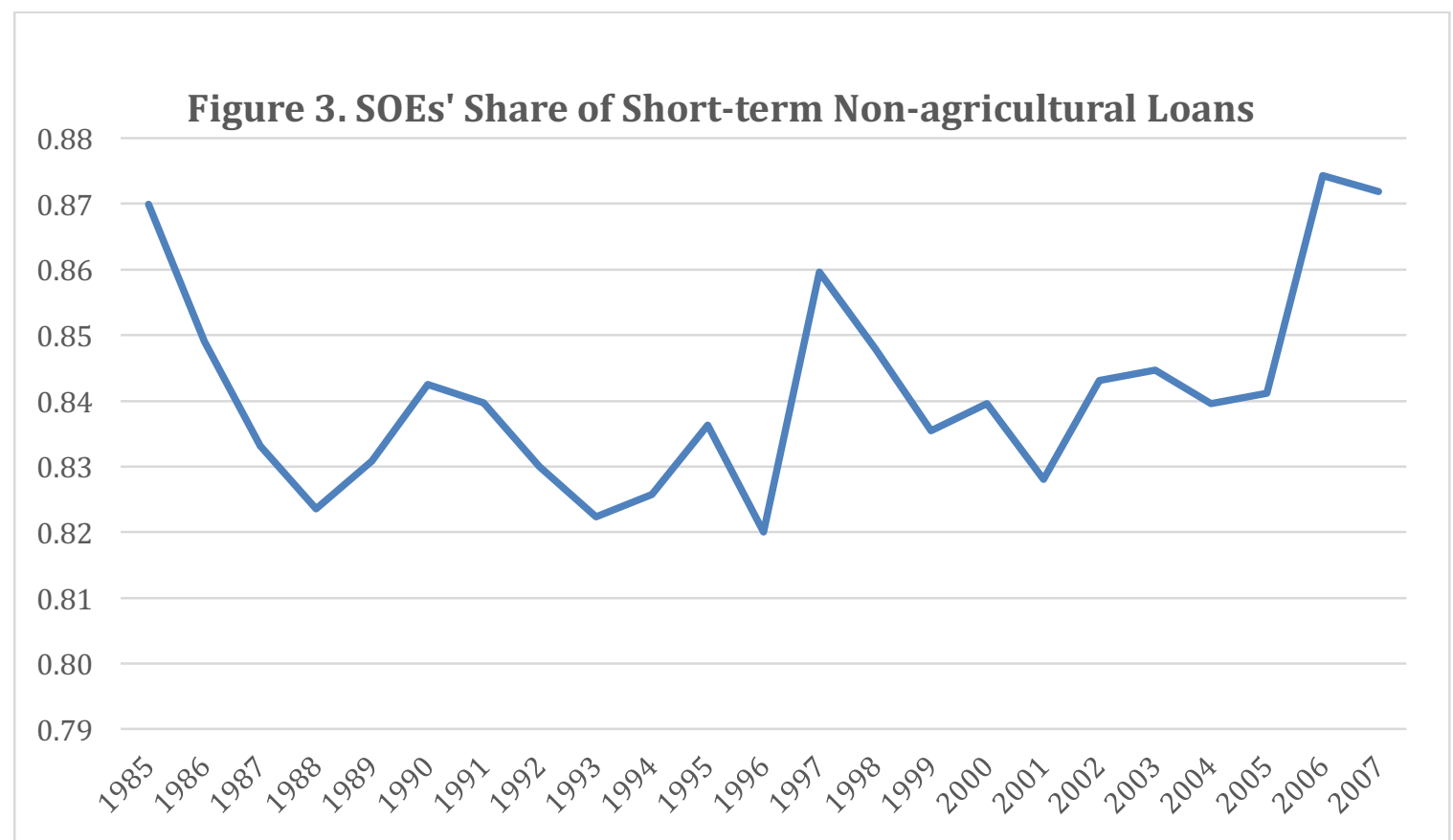

Source: Author's calculation based on data from Almanac of China's Finance and Banking, various years.

The role of the TICs in allocating credits between the state and the non-state enterprises is not as clear as the role of the UCCs and RCCs. On the one hand, the state-owned banks tend to use their affiliated TICs as a way to get around the restrictions of the credit plans so that they can lend to more profitable non-state enterprises. On the other hand, the local governments and large SOEs tend to use the TICs under their control to direct funds to their favorite projects in the state sector. Since there were many bank-affiliated TICs prior to 1996 and all of them were shut down after 1996, one may expect the role of the TICs in credit allocation to be different before and after 1996. In Table 3, I report OLS and Tobit regressions of the SOEs' share of short-term credits on the share of TIC loans as a percentage of loans made by all financial institutions and its interaction with a post-1996 dummy.

The regression results show that over the entire sample period the SOEs' share of total credits was negatively correlated with the share of TIC loans, but not statistically significant. For the period after 1996, however, the correlation between the two shares is significantly positive. These results are consistent with the hypothesis that the bankaffiliated TICs tend to direct credits to the non-state enterprises while the local 
government/SOE controlled TICs direct credit to the state-owned firms. For the period after 1996, because the TICs were mostly controlled by local governments and large SOEs, a $1 \%$ increase in the share of TIC loans is associated with $1.4 \%$ increase in the share of total short-term credits to the SOEs. In contrast, for the period between 1986 and 1996, a $1 \%$ increase in the share of TIC loans is associated with $0.713 \%$ reduction in the SOEs' share of short-term credits due to the lending to the non-state enterprises by the bankaffiliated TICs.

\section{Table 3. The Role of TICs in Credit Allocation}

Dependent variable: SOE's share of short-term credits Sample period: 1986-2009

\begin{tabular}{l|c|c}
\hline \hline Method & OLS & Tobit \\
\hline TIC's loan share & -0.713 & -0.713 \\
& $(0.452)$ & $(0.446)$ \\
Post-96 dummy & & \\
& $-6.994^{* *}$ & $-7.190^{* * *}$ \\
TIC's loan share*Post-96 dummy & $(2.519)$ & $(2.491)$ \\
& $2.115^{* *}$ & $2.210^{* * *}$ \\
& $(0.642)$ & $(0.638)$ \\
Constant & $80.24 * * *$ & $80.24 * * *$ \\
& $(2.318)$ & $(2.289)$ \\
\hline Number of observations & 24 & 24 \\
R-squared & 0.296 & \\
Adjusted. R-squared & 0.190 & \\
Parameter Stability Test Statistics & 0.729 & \\
Structural Break & & \\
\hline
\end{tabular}

Note: Standard errors in parentheses.

$*$ p-value $<10 \%, * *$ p-value $<5 \%$, and $* * *$ p-value $<1 \%$

We use cusum test to test parameter stability. The test statistic is smaller than $10 \%$ critical value and unable to reject the null hypothesis of no structural break 
To recap, before the mid-1990s, China's banking system had become more decentralized with the expansion of the shadow banking sector that included the bank-affiliated TICs, UCCs and RCCs. These institutions were instrumental in directing credits to the more efficient non-state enterprises and therefore improving capital allocation. The banking reform launched in 1994, however, reversed this process of decentralization. The shadow banking sector shrank as the UCCs and RCCs were consolidated into large commercial banks under the control of local governments and the bank-affiliated TICs were shut down. The result is a recentralization of the banking system that had significant negative effect on the non-state sector's access to credits. Consequently, the overall efficiency of capital allocation worsened since the mid-1990s.

\section{The Cause of Banking System Recentralization in the Mid-1990s}

To understand the reason behind the re-centralization of the banking system in the mid1990s, one needs to review the macroeconomic crisis the Chinese central government faced around 1994.

\section{Growth and Inflation Cycles in China before 1996}

Figure 4 plots for each year since 1979 the annual inflation rate and the growth rate of money supply (M1) in the previous year in China. Prior to 1996 China had recurring inflation problems. On the surface the inflation in China then was clearly a monetary phenomenon. There were recurring inflation problems because the central government periodically lost control of money supply growth during that period. The average growth rate of M1 was 22 percent between 1979 and 1995, and the average inflation rate between 1980 and 1996 was more than 9 percent. Furthermore, the peak inflation rate in each cycle was getting higher over time, from 7.5 percent in 1980 to 11.8 percent in $1985,18.7$ percent in 1988, and 24.2 percent in 1994. Brandt and Zhu (2000) examine the fundamental causes of the inflation cycles: the productivity difference between the state and non-state enterprises, the decentralization of the banking system, and the government's commitment to support inefficient state-owned enterprises. I briefly summarize their findings below. 

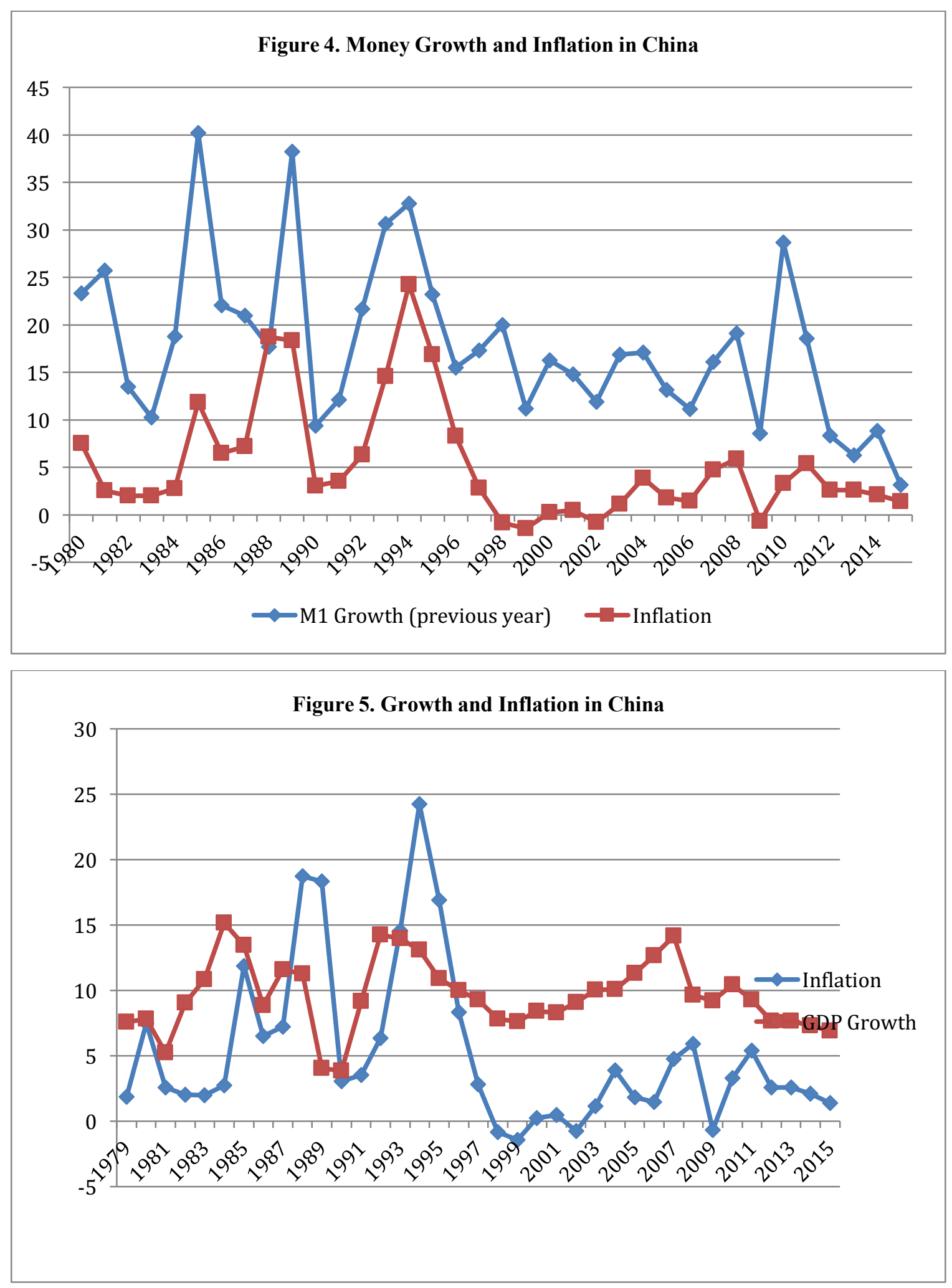

Source: China Statistical Yearbook and author's calculations. 
Until 1998, each year the central government had a detailed investment plan with most of the planned investment projects in the state sector. To finance the investments, the central government also had a detailed credit plan that required the state-owned banks to provide financing for projects in the investment plan. The central government understood that this investment and credit allocation process was highly inefficient, and therefore tried to decentralize the credit allocation process by giving the state-owned banks some discretions in using their funds. However, such discretions were only allowed during years when the inflation rate was low and the credit plan during those years were called indicative plan. Since average returns to investment were higher in the non-state sector than in the state sector, the state-owned banks under indicative plans had strong incentives to move funds to the nonbank lending institutions connected to them so that they could lend to high return projects in the non-state sector. This diversion of funds, however, often resulted in large funding gaps for completing projects within the central government's investment plan. To ensure the completion of planned investment projects in the state sector, then, the PBC was often forced to either provide direct funding for those projects or provide loans to the state-owned banks so that they could provide funding for those projects. So, the diversions of funds by the state-owned banks to non-bank lending institutions had two effects. On the one hand, they provided the more efficient non-state sector with much needed capital, resulting in better capital allocation, higher aggregate TFP and higher GDP growth. On the other hand, it forced the PBC to increase money supply and resulted in higher inflation. When the inflation rate was moderate, the central government tolerated such diversions because of their positive effect on GDP growth. When inflation accelerated, however, the central government was more concerned that high inflation might cause political instability, so controlling inflation became the policy priority. At those times, the central government changed the credit plan from indicative to administrative taking away the discretions in use of funds from the state-owned banks and also cracking down on nonbank lending institutions as we discussed earlier. Such measures resulted in less efficient capital allocation and lower GDP growth rate, but they were effective in controlling diversions of funds by the state-owned banks and therefore eliminating the needs for PBC to finance planned investment projects with money creation. Inflation fell under the administrative plan. For the years prior to 1996 , there were pronounced policy 
cycles when central government policy was regularly switching between indicative and administrative plans. Both GDP growth and money supply growth fluctuated in the same direction as a result of the policy cycles. Figure 5 plots the real GDP growth rates and inflation rates. GDP growth rates generally led inflation as it co-moved with the money supply growth rates.

\section{The Launch of Fiscal, Banking and SOE Reforms in 1994}

In 1993, the combination of the diversions of funds by the state-owned banks to investments in more profitable non-state enterprises and the central government's strong commitment to support the employment in state-owned enterprises with money creation caused the inflation rate to reach a level that was never seen during the communist era and created strong expectation that inflation was out of control. To manage the macroeconomic crisis, Zhu Rongji, then the first vice-premier of the state council and a member of the standing committee of the Chinese Communist Party's political bureau, fired the incumbent head of the PBC and appointed himself as the governor of China's central bank.

Under Zhu Rongji's leadership, the banking reform was launched in 1994. One of the main objectives of the reform is to impose a tighter control of lending by the banking system and eliminate the need for money creation in funding investment projects in the state sector. This was done by shutting down all bank-affiliated TICs, severing the links between the state-owned banks and UCCs an RCCs, and gradually consolidating UCCs and RCCs into urban and rural commercial banks. The result of the banking reform is a much more centralized banking system that favors large firms at the expense of small and medium-sized firms, especially those in the non-state sector.

To further control the inflation risk, Zhu Rongji also implemented a tax reform and started the SOE reform in 1994. Prior to 1994, tax collection was carried out by local governments and, as part of fiscal decentralization, they could negotiate with enterprises about how much taxes each enterprise needs to pay. This along with GDP-based performance assessment provided local governments with strong incentives to lower taxes on productive firms and promoted growth of China's non-state sector. (See, e.g., Li and 
Zhou, 2005,) However, it also implied that the central government received very modest amount of tax revenues. As a percentage of GDP, the central government's tax revenues fluctuated around 10 percent during that period. So, the central government replied heavily on the state-owned banks for supporting investment projects in the state sector. The 1994 tax reform replaced the decentralized tax-contracting system by a centralized valueadded tax system. This reform resulted in a steady increase of the central government's tax revenues as a percentage of GDP and enabled the central government to support state sector investment through fiscal means as well. Also, to reduce the fiscal and monetary burdens of the central government, Zhu Rongji also started the SOE reform that closed or privatized most small and medium-sized money-losing SOEs and corporatized the large SOEs.

The combination of the banking, fiscal and SOE reforms was successful in eliminating the central government's need to use money creation as a way to support the state sector and therefore in controlling inflation after 1996, but it also resulted in the recentralization of the banking system and stronger control of fiscal resources by the central government that led to increases in capital misallocation. The fiscal reform also forced local governments to rely heavily on land sales and loans from the banks under their control, the city commercial banks and rural commercial banks, for financing their fiscal expenditures and their support of local SOEs. When the central government impose restrictions on utilizing these resources by the local governments, they turn to shadow banking activities to get around the restrictions.

\section{The Recent Shadow Banking Activities and Investment Allocation}

Because of the recentralization of the banking system, China's central bank has been able to maintain a relatively tight monetary policy and keep inflation under control for much of the period after 1996. The exception was 2008-2009, when the central government, in response to the global financial crisis, implemented a massive fiscal stimulus. According to Bai, Hsieh and Song (2016), much of the fiscal stimulus was financed by bank loans. As a result, money supply increased dramatically between 2008 and 2009, with M1 grew by almost 30 percent. Not surprisingly, inflation started to rise in 
the following year. To control inflation, the monetary policy was tightened again in 2010 . As pointed out by Allen, Qian, Tu and Yu (2016) and Chen, He and Liu (2017), this tightening put large pressures on local governments (or the local financing vehicles they set up), who needed to roll over the large amount of loans they borrowed from banks in 2008-09. This explains partly the rapid rise of shadow banking activities in China since 2010.

In addition to local government financing, there are other central government policies that may have caused the recent shadow banking growth. In attempts to reduce the risk of housing bubble and deal with overcapacity issue, the central government have implemented policies in recent years that restrict bank lending to real estate sector and to industries with overcapacity. Since local governments in China rely heavily on land sales as a source of fiscal revenues and they worry about employment implications of closing down local factories in overcapacity industries, they have strong incentives to use shadow banking as a way to get around the central government's restrictions and lend to these two type of firms. To what extent the recent growth of shadow banking activities was driven by these motives? I next use the provincial data on shadow banking and investment allocation to examine this question.

Starting in 2014, the PBC started to publish the total social financing and its component for all of the provinces in China in the previous year. So, the data on shadow banking activity by province currently available are for 2013, 2014 and 2015. For each province, I calculated the ratios of three major loans through shadow banking activities - entrusted loans, trust loans, and bankers' acceptances - to bank loans, respectively. From the Fixed Asset Investment Yearbook published by China's National Bureau of Statistics (NBS), I also calculate by province the shares of fixed asset investment in real estate, infrastructure (utilities, transportation, storage and postal services; and water, environment and public facility management), state-owned sector, and private sector, respectively. Table 4 reports panel regressions of each of the investment shares on the previous year's three shadow banking variables, controlling for the level of GDP per capita in a province and year fixed effect. I use the lagged independent variables to reduce the endogeneity problem. Since the 
investment variables are currently only available up to 2016, the panel is a short one with two years and 31 provinces each year. The table reports results from both the OLS and Tobit regressions. Both methods yield similar results. I summarize the main findings below.

Entrusted Loans In both regressions, a province with higher entrusted loan ratio is associated with higher real estate investment. This correlation is the most robust and significant, strongly suggesting that the entrusted loans were mainly used for financing the needs of the real estate sector. Allen, Qian, Tu and Yu (2016) find that a majority of the entrusted loans originated from large SOEs who had easy access to bank loans and the borrowers were mainly affiliated firms of the lenders. Furthermore, they find that the interest rates charged on entrusted loans between affiliated parties are generally low, at levels that are comparable to regular bank loans. This evidence suggests that entrusted loans have been mainly used by the SOEs to get around the central government's restrictions on investment in the real estate.

Trust Loans In both regressions, a province with a higher share of trust loans is associated with higher share of investment in the state sector and lower share of investment in the private sector. This is consistent with the result we reported in Table 3 that, since 1996, loans by trust companies tends to benefit the SOEs rather than the non-SOEs. The reason for this state-sector bias is the fact that most trust companies are controlled by local governments or large SOEs.

Bankers' Acceptances The share of bankers' acceptances has a weak negative correlation with both the state sector's share of investment and the share of infrastructure investment. This result is consistent with the results of $\mathrm{Ho}$, Li, Tian and Zhu (2017), who use loan-level micro data to examine credit allocation before and after the big fiscal stimulus by a stateowned bank in a coastal city in China. They found that before the fiscal stimulus, the bank was treating SOEs and private enterprises (PEs) similarly. After the announcement of the fiscal stimulus, however, the bank's credit allocation was clearly biased towards the SOEs. Relative to the loans to PEs of the same firm characteristics, the loans to SOEs had bigger 
size, lower interest rate and lower credit rating. However, they found no such bias in the lending through the bankers' acceptances. This result suggests that banks may have been using this particular shadow banking channel to avoid the government's policy intervention and allocate credit to more profitable firms or projects. In this sense, the shadow banking activity by the banks are efficiency enhancing, much like their lending through affiliated TICs, UCCs and RCCs in the 1980s and early 1990.

Overall, the empirical results in this section show that the recent shadow banking activities initiated by the local governments and SOEs tend to direct investment to the state sector and reduce the share of investment of the more productive private sector, and therefore result in misallocation of capital. This negative role of local government and SOE initiated shadow banking activities in capital allocation was already apparent in the years after 1996, as evidenced by the regression result reported in Table 3; the rapid expansion of such activities in recent years is argued by Bai, Hsieh and Song (2016) as the reason for the further worsening of capital allocation in China after 2009.

The heavy involvements of the local governments and SOEs in shadow banking activities has also led investors to expect implicit guarantees of shadow banking products, and therefore distort the market pricing of the underlying risk of the investments financed by these products. ${ }^{4}$ The distortion in the pricing of risk helps to fuel the rapid growth of these products and increases the systematic risk of the economy by exposing both investors and local governments and SOEs to the underlying risk of the investment projects finance by these products.

For the shadow banking activities initiated by the banks, however, the empirical results reported in Table 4 show that they have no bias towards the state sector. In fact, higher share of shadow-banking loans by the banks implies higher (though not statistically significant) share of investment in the private sector.

\footnotetext{
${ }^{4}$ For example, Allen, Gu, Qian and Qian (2017) show that the expectation of implicit guarantees flattens the spread-to-risk relationship for trust products in China.
} 


\section{Conclusions}

Shadow banking activities in China arose from the need to get around the central government's lending restrictions. It is not a new phenomenon. There were significant shadow banking activities in China before 1996. There are two types of shadow banking activities, those initiated by the banks, which tend to be efficiency enhancing, and those initiated by the local governments or SOEs, which tend to result in capital misallocation. China's banking reform launched in 1994 reduced the shadow banking activities in general, and those initiated by banks in particular. The banking system also became much more centralized after the reform. This is a main reason for the increase in capital misallocation in China since the mid-1990s.

The recent shadow banking activities have been dominated by local governments and SOEs. Cross-province evidence suggests that these government initiated shadow banking activities tend to help local governments or SOEs to get around the central government's restrictions on investments in real estate and increase investments in the state sector at the expense of reducing investments in the more productive private sector. Such activities worsen the capital misallocation problem in China and also increase the systematic risk in the economy because of the expectation of implicit guarantees provided by the local governments and SOEs. Given these negative roles played by the local governments and SOEs, the policy implication is that the central government should implement policies and regulations that break the links between the financial institutions and local governments or SOEs so that they cannot use shadow banking as a way to finance fiscal expenditures, support inefficient SOEs or speculate in the real estate market.

I should note that most of the evidence I provide in this paper is suggestive rather than conclusive. Future research should make effort in collecting more detailed institutional level micro-data to examine the relationship between shadow banking activities and real activities in a more granular way. However, I hope the historical time-series evidence and the cross-province evidence of recent years I provided in this paper form a coherent narrative about the evolution of China's banking system and its real impacts, and shed some light on the role of shadow banking activities on capital allocation in China. 
Table 4. Shadow Bank Lending and Investment Allocation

Sample: 31 provinces and two years (2015 and 2016)

Dependent variables: Investment shares by sector

\begin{tabular}{|c|c|c|c|c|c|c|c|c|}
\hline & \multicolumn{4}{|c|}{ OLS Regressions } & \multicolumn{4}{|c|}{ Tobit Regressions } \\
\hline & (1) & $(2)$ & (3) & (4) & (5) & (6) & (7) & (8) \\
\hline & Real Estate & Infrastructure & State & Private & Real Estate & Infrastructure & State & Private \\
\hline \multirow[t]{2}{*}{ Entrusted_Loan (t-1) } & $0.379 * * *$ & -0.0926 & -0.141 & -0.0623 & $0.395 * * *$ & -0.0956 & -0.147 & -0.0707 \\
\hline & $(0.0992)$ & $(0.0656)$ & $(0.104)$ & $(0.0989)$ & $(0.0975)$ & $(0.0641)$ & $(0.102)$ & $(0.0970)$ \\
\hline \multirow[t]{2}{*}{ Trust_Loan (t-1) } & -0.0287 & 0.0680 & $0.167 * *$ & $-0.123^{*}$ & -0.0309 & 0.0690 & $0.171 * *$ & $-0.121 *$ \\
\hline & $(0.0660)$ & $(0.0436)$ & $(0.0691)$ & $(0.0658)$ & $(0.0644)$ & $(0.0427)$ & $(0.0677)$ & $(0.0644)$ \\
\hline \multirow[t]{2}{*}{ BankAcceptance_Loan (t-1) } & -0.110 & -0.122 & $-0.211^{*}$ & 0.0852 & -0.123 & $-0.144^{*}$ & $-0.226^{*}$ & 0.0859 \\
\hline & $(0.116)$ & (0.0770) & $(0.122)$ & $(0.116)$ & $(0.114)$ & $(0.0768)$ & $(0.120)$ & $(0.114)$ \\
\hline \multirow[t]{2}{*}{ log_GDP_pc (t-1) } & 0.0459 & $-0.0708 * * *$ & $-0.118^{* * *}$ & 0.00275 & 0.0465 & $-0.0731 * * *$ & $-0.118^{* * *}$ & 0.00359 \\
\hline & $(0.0376)$ & $(0.0249)$ & $(0.0394)$ & $(0.0375)$ & $(0.0368)$ & $(0.0243)$ & $(0.0386)$ & $(0.0368)$ \\
\hline \multirow[t]{2}{*}{ Constant } & -0.300 & $1.017 * * *$ & $1.583 * * *$ & 0.290 & -0.309 & $1.043 * * *$ & $1.586 * * *$ & 0.282 \\
\hline & $(0.394)$ & $(0.261)$ & $(0.413)$ & $(0.393)$ & $(0.385)$ & $(0.255)$ & $(0.404)$ & $(0.385)$ \\
\hline Year FE & $Y$ & $\mathrm{Y}$ & $\mathrm{Y}$ & $Y$ & $Y$ & $Y$ & $\mathrm{Y}$ & $\mathrm{Y}$ \\
\hline Obs & 62 & 62 & 62 & 62 & 62 & 62 & 62 & 62 \\
\hline $\mathrm{R}-\mathrm{sq}$ & 0.279 & 0.261 & 0.345 & 0.139 & & & & \\
\hline
\end{tabular}




\section{References}

Acharya, V Viral, Jun Qian, and Zhishu Yang (2016) "In the shadow of banks: wealth management products and issuing banks' risk in China." Working paper.

Allen, Franklin, Yiming Qian, Guoqian Tu, and Frank Yu (2016) "Entrusted loans: A close look at China's shadow banking system." Working paper.

Allen, Franklin, Xian Gu, Jun Qian, and Yiming Qian (2017) "Implicit guarantee and the rise of shadow banking: The case of trust products." Presentation at the $1^{\text {st }}$ FISF Economics and Finance Workshop.

Ambrose, Brent W, Yongheng Deng, and Jing Wu (2015) "Understanding the risk of China's local government debts and its linkage with property markets." Working paper.

Ang, Andrew, Jennie Bai, and Hao Zhou (2016) "The great wall of debt: Real estate, corruption, and Chinese local government credit spreads." Working paper.

Bai, Chong-En, Chang-Tai Hsieh, and Zheng(Michael) Song (2016) "The long shadow of China's fiscal expansion." Brookings Papers on Economic Activity 60, 309-327.

Brandt, Loren and Xiaodong Zhu (1995) "Financial reform and the role of non-bank financial institutions in China." Unpublished report prepared for J.P. Morgan Securities Inc.

Brandt, Loren and Xiaodong Zhu (2000) "Redistribution in a decentralized economy: growth and inflation in China under reform." Journal of Political Economy, 108 (2).

Brandt, Loren and Xiaodong Zhu (2007) "China's banking sector and economic growth." in Charles Calomiris (ed.) China's Financial Transition at Cross Road, pp.86-136, Columbia University Press, New York.

Chang, Chun, Kaiji Chen, Waggoner and Tao Zha (2015) “Trend and cycles in China's macroeconomy." NBER Macroeconomic Annual 30.

Chen, Kaiji, Jue Ren, and Tao Zha (2017) "The Nexus of monetary policy and shadow banking in China." NBER Working Paper 23377

Chen, Zhou, Zhiguo He, and Chun Liu (2017) "The Financing of local government in China: Stimulus loans wane and shadow banking waxes." Working paper, Booth School of Business, University of Chicago.

Cong, Will, and Jacopo Ponticelli (2016) "Credit allocation under economic stimulus: 
Evidence from China." Working paper, Booth School of Business, University of Chicago.

Elliot, Douglas, Arthur Kroeber, and Yu Qian (2015) "Shadow banking in China, A primer." Brookings Economic Studies.

Hachem, Kinda, and Zheng Michael Song (2015) "The rise of China's shadow banking System.” Working paper, Booth School of Business, University of Chicago.

Ho, Chun-Yu, Dan Li, Suhua Tian and Xiaodong Zhu (2017) "Policy distortion in credit allocation: Evidence from China's fiscal stimulus plan." Unpublished manuscript.

Huang, Yi, Marco Pagano, and Ugo Panizza (2016) "Public debt and private firm funding: Evidence from Chinese cities." Working Paper, The Graduate Institute (Geneva) and University of Naples Federico II.

Kumar, Anjali, Nicholas Lardy, William Albrecht, Terry Chuppe, Susan Selwyn, Paula Perttunen, and Tao Zhang (1996) "China's non-bank financial institutions: Trust and Investment companies.” World Bank Discussion Paper No. 358.

Li, Hongbin, and Li-An Zhou (2005) "Political turnover and economic performance: the incentive role of personnel control in China." Journal of Public Economics 89, 17431762.

Sheng, Andrew, Christian Edelmann, Cliff Sheng, and Jordi Hu (2015) "Bring light upon the shadow: A review of the Chinese shadow banking sector." Oliver Wyman and Fung Global Institute Report.

Sun, Guofeng, and Junyi Jia (2015) "Defining China's shadow banking and assessing its scale: Seen in terms of the money creation." In Chinese, Zhongguo Shehui Kexue, 92.

Wang, Hao, Honglin Wang, Lisheng Wang, and Hao Zhou (2016) "Shadow banking: China's dual-track interest rate liberalization.” Working Paper, Tsinghua-PBC School Of Finance.

Wang, Chunyang (2017) "Crony banking and local growth in China." BOFIT Discussion Paper, Bank of Finland. 